Original Research Paper

\title{
Penerapan Algoritma Knuth-Morris-Pratt pada Fungsi Pencarian Dokumen untuk Sistem Informasi Administrasi Sekolah Berbasis Website
}

\author{
Imam Maulana ${ }^{1}$, Normalisa ${ }^{1}$ \\ ${ }^{1}$ Program Studi Teknik Informatika, Fakultas Teknik, Universitas Pamulang, \\ Tanggerang Selatan, Indonesia
}

Article History

Received:

09.01.2019

Revised:

20.02.2019

Accepted:

03.03.2019

*Corresponding Author:

Normalisa

Email:

dosen00377@unpam.ac.id

This is an open access article, licensed under: $\mathrm{CC}-\mathrm{BY}-\mathrm{SA}$

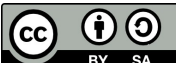

Abstrak: Algoritma Knuth-Morris-Pratt merupakan algoritma pencarian yang akan mencocokkan pattern atau susunan kata yang akan dicari dari kiri ke kanan pada awal teks dan kemudian menggeser susunan kata sampai susunan kata tersebut berada di ujung teks. Algoritma KMP memiliki keunggulan pencarian kecocokan pada file yang berukuran besar. Metode pengembangan sistem yang digunakan yaitu metode Rapid Application Development. Metode RAD ini adalah strategi siklus hidup yang ditujukan untuk menyediakan pengembangan yang jauh lebih cepat dan mendapatkan hasil dengan kualitas yang lebih baik dibandingkan dengan hasil yang dicapai melalui siklus tradisional. Aplikasi Sistem Informasi Administrasi Sekolah ini diharapkan dapat mengatasi permasalahan yang timbul dari proses pengendalian dokumen secara konvensional agar lebih mudah dan tepat.

Kata Kunci: Knuth-Morris-Pratt, Pencarian Dokumen, Rapid Application Development.

Applying of Knuth-Morris-Pratt Algorithm to the Document Search Function for Website-Based School Administration Information Systems

Abstract: Knuth-Morris-Pratt algorithm is a search algorithm that will match the pattern or arrangement of words to be searched from left to right at the beginning of the text and then shift the order of words until the word order is at the end of the text. The KMP algorithm has the advantage of matching matches on large files. The system development method used is the Rapid Application Development method. RAD method is a life cycle strategy aimed at providing development that is much faster and gets results with better quality compared to results achieved through traditional cycles. Application of School Administration Information System is expected to be able to overcome problems arising from conventional document control processes to make it easier and more precise.

Keywords: Document Search, Knuth-Morris-Pratt, Rapid Application Development. 


\section{Pendahuluan}

Saat ini proses pengendalian dokumen pada SMK Teknologi Informatika YPML masih dilakukan secara konvensional yaitu dokumen dibuat dengan menggunakan program pengolah kata, kemudian dokumen dicetak untuk selanjutnya dikelola sesuai dengan prosedur pengendalian dokumen yang ada. Dokumen yang dikelola akan terus bertambah seiring berjalannya waktu sehingga menyimpan dokumen secara konvensional di dalam map arsip tentu akan menyulitkan ketika mencari dokumen yang sedang dibutuhkan tentunya membuat pekerjaan tenaga administrasi sekolah tidak efektif dan efisien. Selain itu, penyimpanan dokumen secara konvensional tanpa adanya salinan secara elektronik memiliki resiko seperti kehilangan dan kerusakan dokumen.

Solusi untuk mengatasi masalah tersebut yaitu diperlukan sistem pengelolaan dokumen yang terkomputerisasi sehingga dapat membantu proses pengendalian dokumen pada SMK Teknologi Informatika YPML. Fungsi pencarian dokumen pada sistem informasi administrasi sekolah menggunakan algoritma Knuth-Morris-Pratt. Algoritma Knuth-Morris-Pratt (KMP) ini merupakan algoritma pencarian String untuk mencari teks berdasarkan urutan dari kiri ke kanan. Algoritma KMP akan mencocokkan pattern atau susunan kata yang akan dicari dari kiri ke kanan pada awal teks dan kemudian menggeser susunan kata sampai susunan kata tersebut berada di ujung teks [1]. Algoritma KMP memiliki keunggulan pencarian kecocokan pada file yang berukuran besar [2].

Metode pengembangan sistem yang digunakan yaitu metode Rapid Application Development (RAD) yang memiliki strategi siklus hidup yang ditujukan untuk menyediakan pengembangan yang jauh lebih cepat dan mendapatkan hasil dengan kualitas yang lebih baik dibandingkan dengan hasil yang dicapai melalui siklus tradisional [3]. Pemodelan sistem menggunakan Unified Modeling Language (UML) dikarenakan UML menyediakan bahasa pemodelan visual yang memungkinkan bagi pengembang sistem untuk membuat cetak biru atas visi mereka dalam bentuk yang baku, mudah dimengerti, serta dilengkapi dengan mekanisme yang efektif untuk berbagi dan mengkomunikasikan rancangan mereka dengan yang lain [4]. Selanjutnya, rancangan sistem tersebut akan diimplementasikan ke dalam aplikasi berbasis website dengan menggunakan bahasa pemrograman PHP dan database menggunakan MySQL.

\section{Tinjauan Pustaka}

\subsection{Algoritma String Matching}

Algoritma String Matching adalah sebuah algoritma yang digunakan dalam pencocokkan suatu pola kata tertentu terhadap suatu kalimat atau teks panjang. Algoritma string matching sendiri dapat dilakukan dengan beberapa cara tertentu, antara lain cara Brute Force dan cara Knuth-Morris-Pratt (KMP) [1].

\subsection{Algoritma Knuth-Morris-Pratt}

Algoritma Knuth-Morris-Pratt dikembangkan secara terpisah oleh Donald E. Knuth pada tahun 1967 dan James H. Morris bersama Vaughan R. Pratt pada tahun 1966, namun keduanya mempublikasikannya secara bersamaan pada tahun 1977 [5]. Algoritma Knuth-Morris-Pratt dilakukan dengan cara menghitung fungsi pinggiran dari pola terlebih dulu dan kemudian akan dilakukan perbandingan antara pola dan elemen pertama dari kalimat, jika tidak sesuai, maka perbandingan tidak dilakukan pada elemen kedua, namun tergantung dari nilai yang akan dikeluarkan oleh fungsi pinggiran tersebut [1].

\subsection{Dokumen}

Dokumen adalah surat yang tertulis atau tercetak yang dapat dipakai sebagai bukti keterangan, barang cetakan atau naskah karangan yang dikirim melalui pos, atau rekaman suara, gambar dalam film, dan sebagainya yang dapat dijadikan bukti keteranga. Dokumen adalah informasi yang dikumpulkan dan bisa diakses serta digunakan [6].

\subsection{Konsep Dasar Sistem}

Sistem merupakan bagian yang saling berkaitan erat dan membentuk suatu kesatuan yang saling berinteraksi antara bagian satu dengan bagian lainnya untuk mencapai suatu tujuan, artinya apabila salah satu bagian dari sistem tidak ada maka sistem tersebut tidak berfungsi sebagaimana mestinya. Suatu sistem dapat terdiri dari bagian-bagian sistem (subsistem) yang saling berinteraksi, sebagai akibat dari adanya input yang diproses menjadi output / informasi, misalnya sebuah komputer terdiri 
dari beberapa komponen [7].

\subsection{Sistem Informasi}

Sistem informasi dapat merupakan kombinasi teratur dari orang-orang, hardware, software, jaringan komputer dan sumber daya data yang mengumpulkan, mengubah, dan menyebarkan informasi dalam sebuah organisasi [8]. Sistem informasi adalah sebuah sistem yang menyajikan informasi guna mendukung fungsi operasi, manajemen, dan pengambilan keputusan dalam sebuah organisasi [9]. Tujuan dari sistem informasi itu adalah menyajikan informasi untuk mengambil keputusan pada perencanaan, pengorganisasian, pengendalian kegiatan operasi subsistem pada perusahaan dan menyajikan sinergi organisasi [9].

Sistem informasi adalah suatu sistem di dalam organisasi yang mempertemukan pengolahan transaksi harian, mendukung operasi, bersifat manajerial dan kegiatan strategic suatu organisasi, serta menyediakan pihak luar tertentu dengan laporan-laporan yang dibutuhkan [10]. Sistem informasi adalah suatu sistem di dalam organisasi yang merupakan kombinasi dari orang-orang, teknologi, fasilitas, prosedur dan pengendalian yang ditujukan untuk mengolah data menjadi informasi yang penting sehingga dapat digunakan sebagai pengambilan keputusan [9].

\section{Metode Penelitian}

\subsection{Analisa Sistem}

Analisa sistem merupakan kegiatan penguraian suatu sistem informasi yang utuh dan nyata kedalam bagian-bagian atau kelompok komponen-komponen yang bertujuan untuk mengidentifikasi serta mengevaluasi masalah-masalah yang muncul, hambatan-hambatan yang sering terjadi, serta kebutuhan yang diharapkan, sehingga dapat memberikan solusi untuk perbaikan maupun pengembangan kearah yang lebih baik dan sesuai dengan kebutuhan pengguna dan perkembangan teknologi.

\subsection{Analisa Sistem Saat Ini}

Analisis sistem saat ini diketahui melalui kegiatan wawancara dengan perwakilan SMK Teknologi Informatika YPML serta observasi langsung di lapangan, prosedur pengelolaan dan pengendalian dokumen yang meliputi kegiatan pembuatan, penerbitan, pendistribusian, pemeliharaan, pengubahan, dan pemusnahan dokumen. Activity diagram proses pembuatan, penerbitan dan pendistribusian dokumen pada sistem saat ini dapat dilihat pada Gambar 1.

\subsection{Analisa Proses Pemeliharaan Dokumen}

Kepala sekolah secara berkala mengidentifikasi kesesuaian semua dokumen yang digunakan dalam daftar induk termasuk dokumen eksternal. Apabila ditemukan dokumen yang tidak sesuai dan atau sudah tidak berlaku, maka kepala sekolah menarik dokumen tersebut, memasukkan ke dalam folder tidak berlaku atau kadaluwarsa dan diganti dengan dokumen yang sesuai. Kepala sekolah menyerahkan dokumen yang sudah tidak berlaku atau kadaluawarsa ke Sub-bagian yang berhubungan dengan penyimpanan atau pemusnahan sesuai dengan jadwal arsip sekolah. Activity diagram pemeliharaan dokumen yang dilakukan pada sistem saat ini dapat dilihat pada Gambar 2.

\subsection{Analisa Proses Pengubahan Dokumen}

Proses pengubahan yang bersifat amandemen, dibuat dalam lembar amandemen sesuai Formulir Amandemen. Kepala sekolah menggandakan hasil amandemen, diberi cap copy dan no, dan mendistribusikannya sesuai daftar distribusi dokumen untuk disisipkan pada dokumen yang diamandemen.

\subsection{Analisa Proses Pemusnahan Dokumen}

Pemusnahan dokumen dapat dilakukan dengan cara dibakar, dicacah atau dijadikan bubur kertas, atau cara lain sehingga fisik dan informasinya tidak dapat dikenali lagi. 
Imam Maulana, Normalisa.

Penerapan Algoritma Knuth-Morris-Pratt pada Fungsi Pencarian Dokumen untuk Sistem Informasi Administrasi Sekolah Berbasis Website.

International Journal of Artificial Intelligence, vol. 6, no. 1, pp. 1-20, June 2019. DOI: 10.36079/lamintang.ijai-0601.30

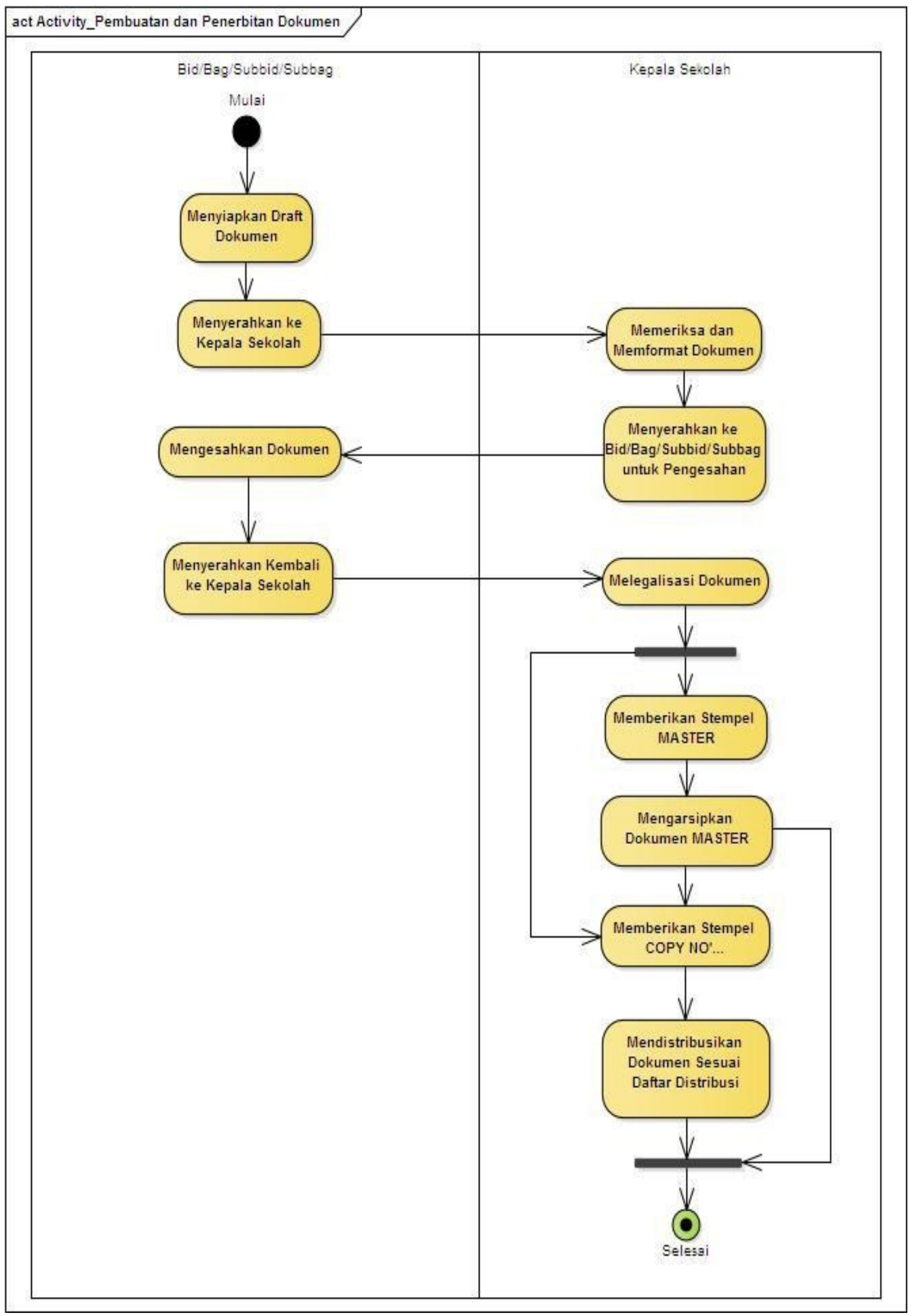

Gambar 1. Activity Diagram Pembuatan, Penerbitan dan Pendistribusian Dokumen 


\subsection{Evaluasi Sistem Saat Ini}

Setelah dilakukan observasi, ditemukan beberapa hal yang terjadi diantaranya:

1. Belum adanya sistem terkomputerisasi yang digunakan sebagai rekomendasi kepada kepala sekolah dalam hal melakukan pengendalian dokumen.

2. Belum adanya database terkomputerisasi sehingga beresiko terjadi kerusakan atau kehilangan ketika menyimpan dokumen di dalam map arsip.

3. Belum adanya metode pencarian dokumen untuk membantu dalam mencari dokumen yang dibutuhkan.

\subsection{Analisa Sistem yang Diusulkan}

Aplikasi Sistem Informasi Administrasi Sekolah yang dapat membantu SMK Teknologi Informatika YPML untuk melakukan pengelolaan dan pengendalian dokumen adalah sebagai berikut:

1. Dibuatnya sistem informasi untuk memudahkan pengendalian dokumen SMK Teknologi Informatika YPML.

2. Dibangunnya struktur database yang mampu menyimpan data dokumen secara digital sebagai backup apabila dokumen fisik hila ng atau rusak.

3. Proses pencarian dokumen menggunakan algoritma Knuth-Morris- Pratt (KMP) agar proses menjadi lebih tepat.

\subsection{Perancangan Sistem}

Pada bagian ini dijelaskan tentang perancangan sistem meliputi perancangan basis data (database), perancangan alur sistem keseluruhan dan perancangan tampilan user interface.

\subsubsection{Perancangan Basis Data}

Perancangan basis data meliputi perancangan Entity Relationship Diagram (ERD), Transformasi ERD ke LRS, dan Logical Record Structure (LRS). Entity Relationship Diagram disajikan pada Gambar 5.

Transformasi ERD ke LRS disajikan pada Gambar 6. Setelah ditransformasikan ERD ke LRS, maka bentuk Logical Record Structure (LRS) yang sudah terbentuk seperti dapat dilihat pada Gambar 7.

\subsubsection{Spesifikasi Basis Data}

Spesifikasi basis data merupakan penguraian field-field dari setiap tabel yang meliputi, nama field, tipe data, panjang data, dan keterangan. Spesifikasi basis data meliputi data user, Organisasi, Pangkat Golongan, Dokumen, Autentikasi Dokumen, Jenis Dokumen, Daftar Induk Dokumen, File Distribusi, dan Usulan Dokumen.

Contoh spesifikasi data User dapat dilihat pada Tabel 1.

\subsection{Perancangan Aplikasi}

\subsubsection{Use Case Diagram}

Use case diagram dari sistem yang dirancang dan dibangun disajikan pada Gambar 8. Deskripsi Use Case sebagai berikut:

1. Users (Admin, User) melakukan login pada Sistem Informasi Administrasi Sekolah.

2. Users dapat memilih menu Tambah Dokumen untuk menambah dokumen baru.

3. User melakukan Autentikasi Dokumen berupa penyiapan dokumen, pemeriksaan dokumen, dan pengesahan dokumen sesuai wewenang User.

4. Admin melakukan Kendali Dokumen yang telah disiapkan, diperiksa, dan disahkan oleh user yang berwenang.

5. Users dapat membuat Usulan Dokumen berupa amandemen, maupun pemusnahan dokumen yang tidak berlaku.

6. Users dapat Melihat Dokumen Terkendali yang telah dipublikasi oleh Admin.

7. Admin dapat Mengelola Data Users yang menggunakan Sistem Informasi Administrasi Sekolah.

8. Admin dapat Mengelola Data Template Dokumen yang akan diunduh oleh Users.

9. Users dapat melakukan pencarian data dengan algoritma Knuth-Morris-Pratt.

10. Users dapat melakukan Logout untuk keluar dari Sistem Informasi Administrasi Sekolah. 


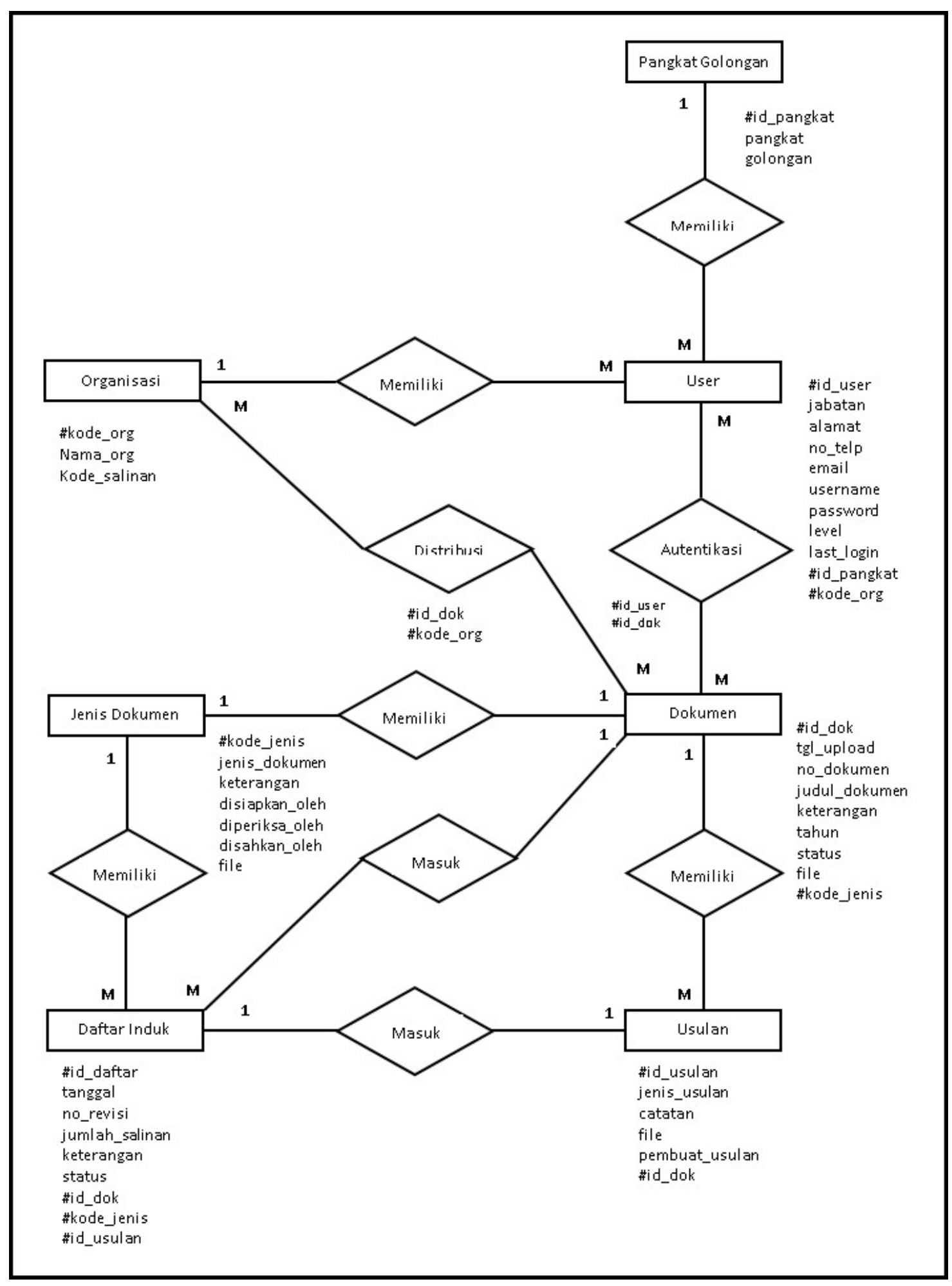

Gambar 2. Entity Relationship Diagram 


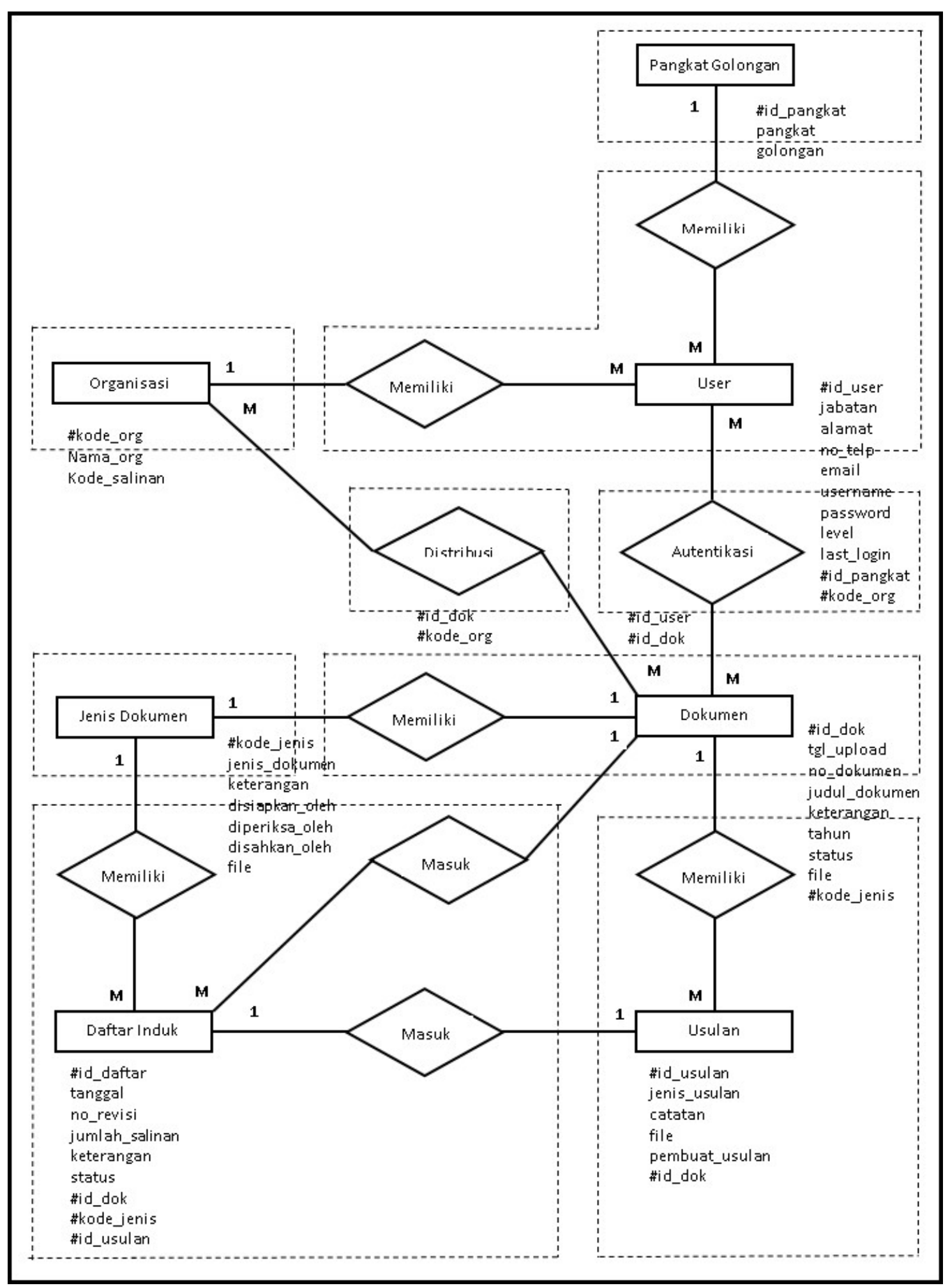

Gambar 3. Transformasi ERD ke LRS 


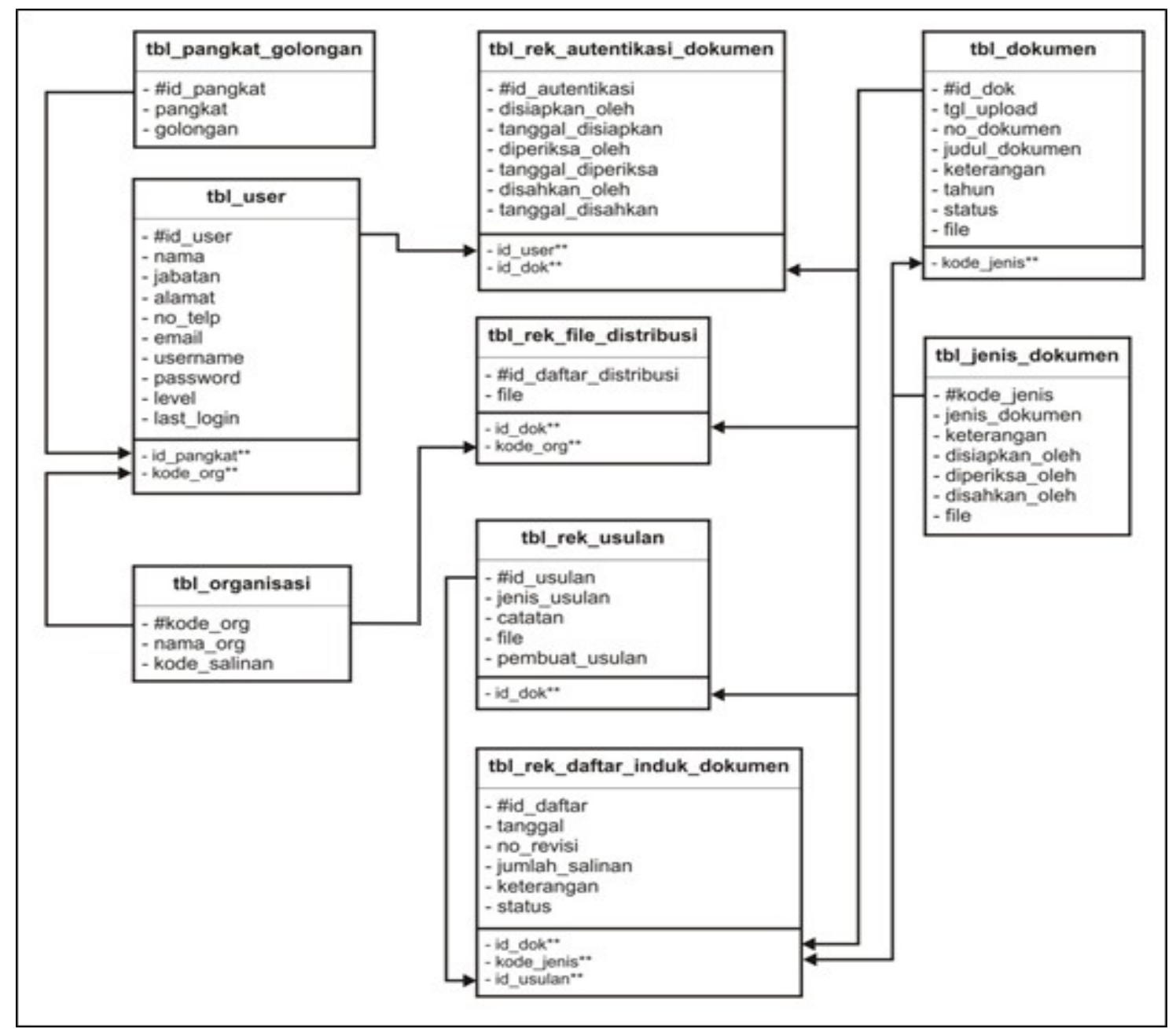

Gambar 4. Logical Record Structure

Tabel 1. Tabel Database User

\begin{tabular}{c|c|c|c}
\hline Field & Type & Length & Indeks \\
\hline id_user & Int & 11 & Primary Key \\
\hline Nama & Varchar & 50 & - \\
\hline Jabatan & Enum & Kepala, Staff & - \\
\hline Alamat & text & - & - \\
\hline no_telp & Varchar & 13 & - \\
\hline Email & Varchar & 30 & - \\
\hline Username & Varchar & 50 & Unique \\
\hline Password & Varchar & 255 & - \\
\hline Level & Enum & Admin, User & - \\
\hline last_login & Varchar & 30 & - \\
\hline kode_org & Varchar & 30 & Foreign Key \\
\hline id_pangkat & Int & 11 & Foreign Key \\
\hline
\end{tabular}


Imam Maulana, Normalisa.

Penerapan Algoritma Knuth-Morris-Pratt pada Fungsi Pencarian Dokumen untuk Sistem Informasi Administrasi Sekolah Berbasis Website.

International Journal of Artificial Intelligence, vol. 6, no. 1, pp. 1-20, June 2019. DOI: 10.36079/lamintang.ijai-0601.30

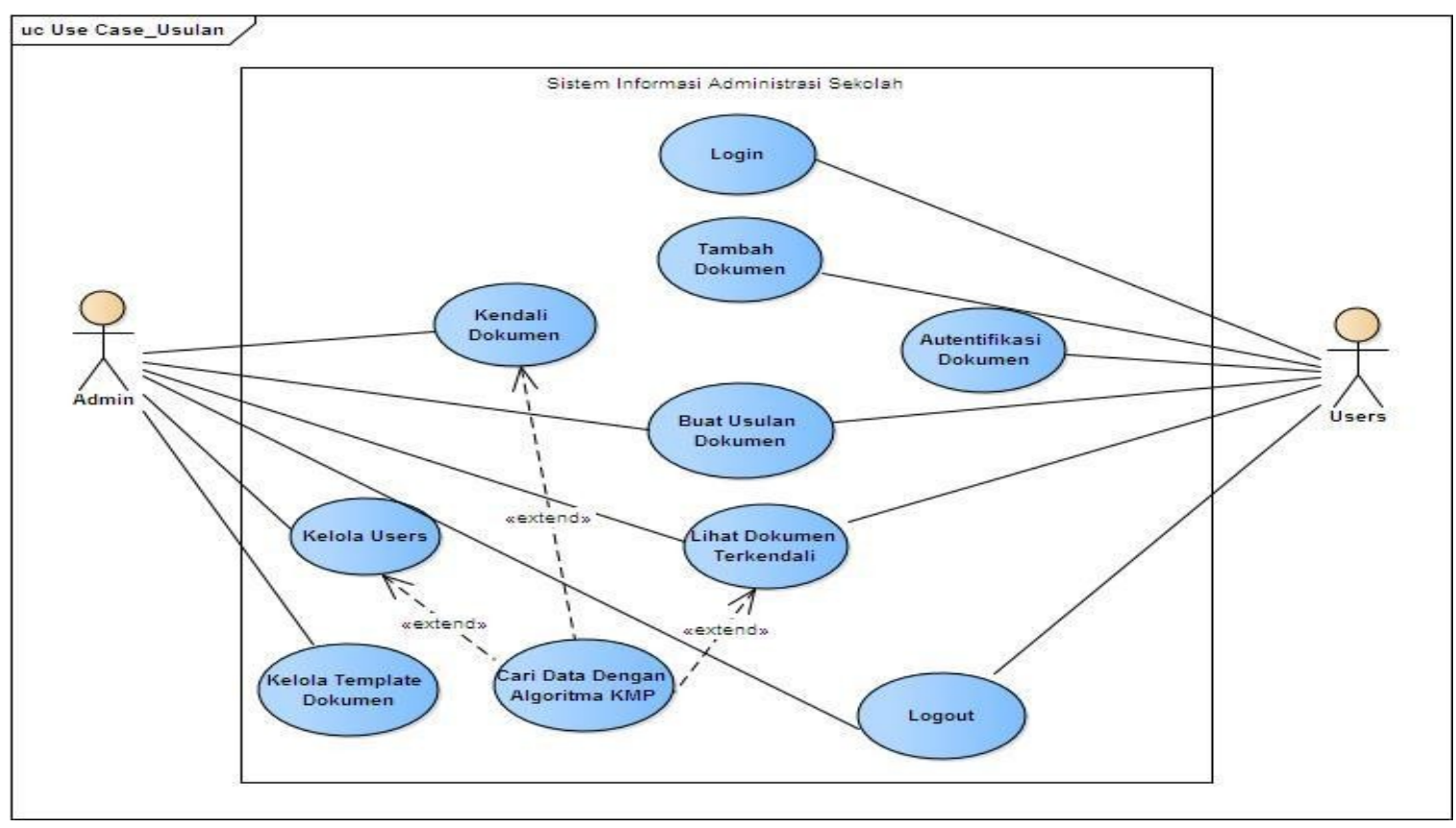

Gambar 5. Use Case Diagram

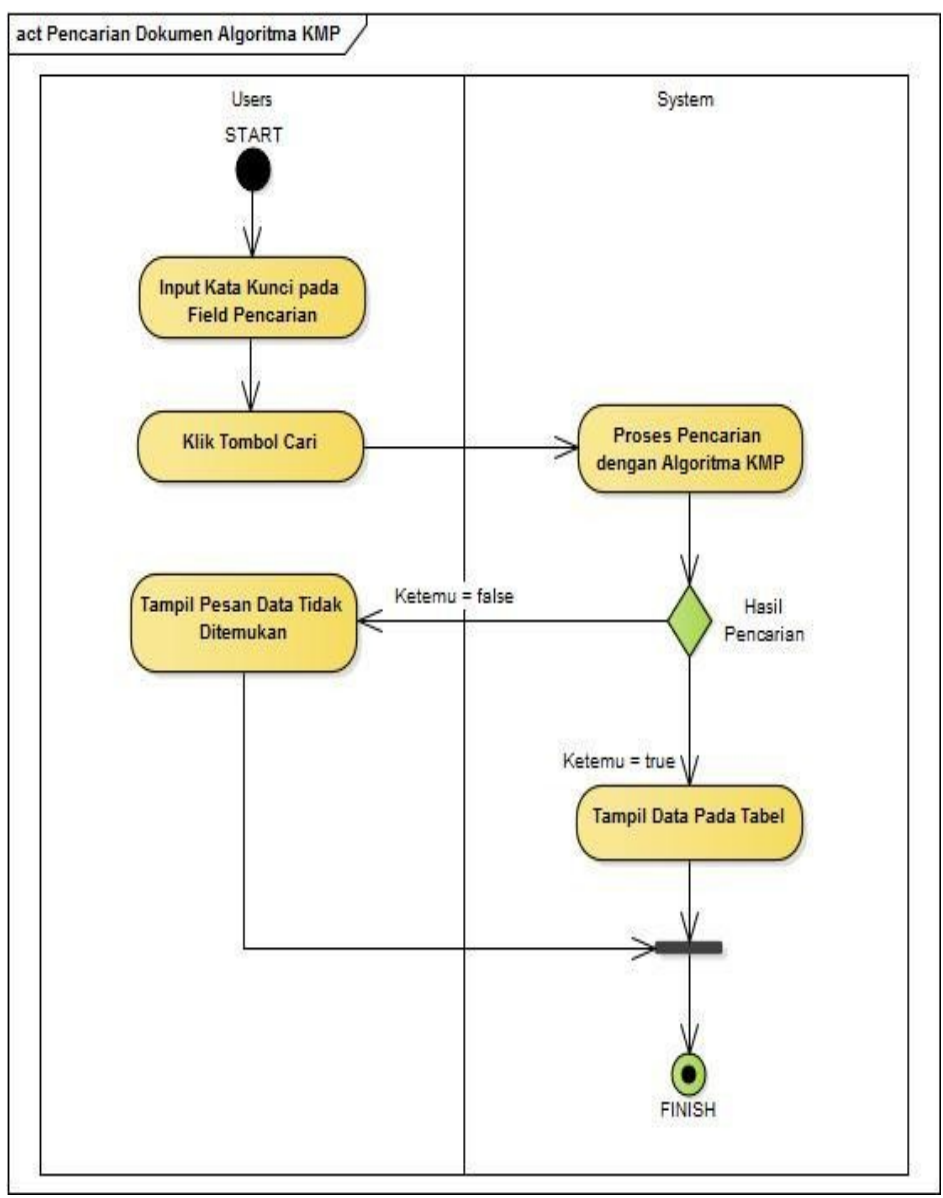

Gambar 6. Activity Diagram Pencarian Data Algoritma KMP 
Imam Maulana, Normalisa.

Penerapan Algoritma Knuth-Morris-Pratt pada Fungsi Pencarian Dokumen untuk Sistem Informasi Administrasi Sekolah Berbasis Website.

\subsubsection{Activity Diagram}

Beberapa activity diagram pada penelitian ini adalah activity diagram Login dan Tambah Dokumen, Autentikasi Dokumen dan Kendali Dokumen, Lihat Dokumen Terkendali dan Pencarian Data Algoritma KMP, Usulan Dokumen dan Kelola User, Kelola Template Dokumen dan Logout.

Activity diagram pencarian data algoritma KMP disajikan pada Gambar 6.

\subsubsection{Sequence Diagram}

Diagram sequence merupakan penjelasan secara detail dari masing-masing activity diagram yang telah dijelaskan sebelumnya. Contoh sequence diagram Pencarian Data Algoritma KMP dapat dilihat pada Gambar 7.

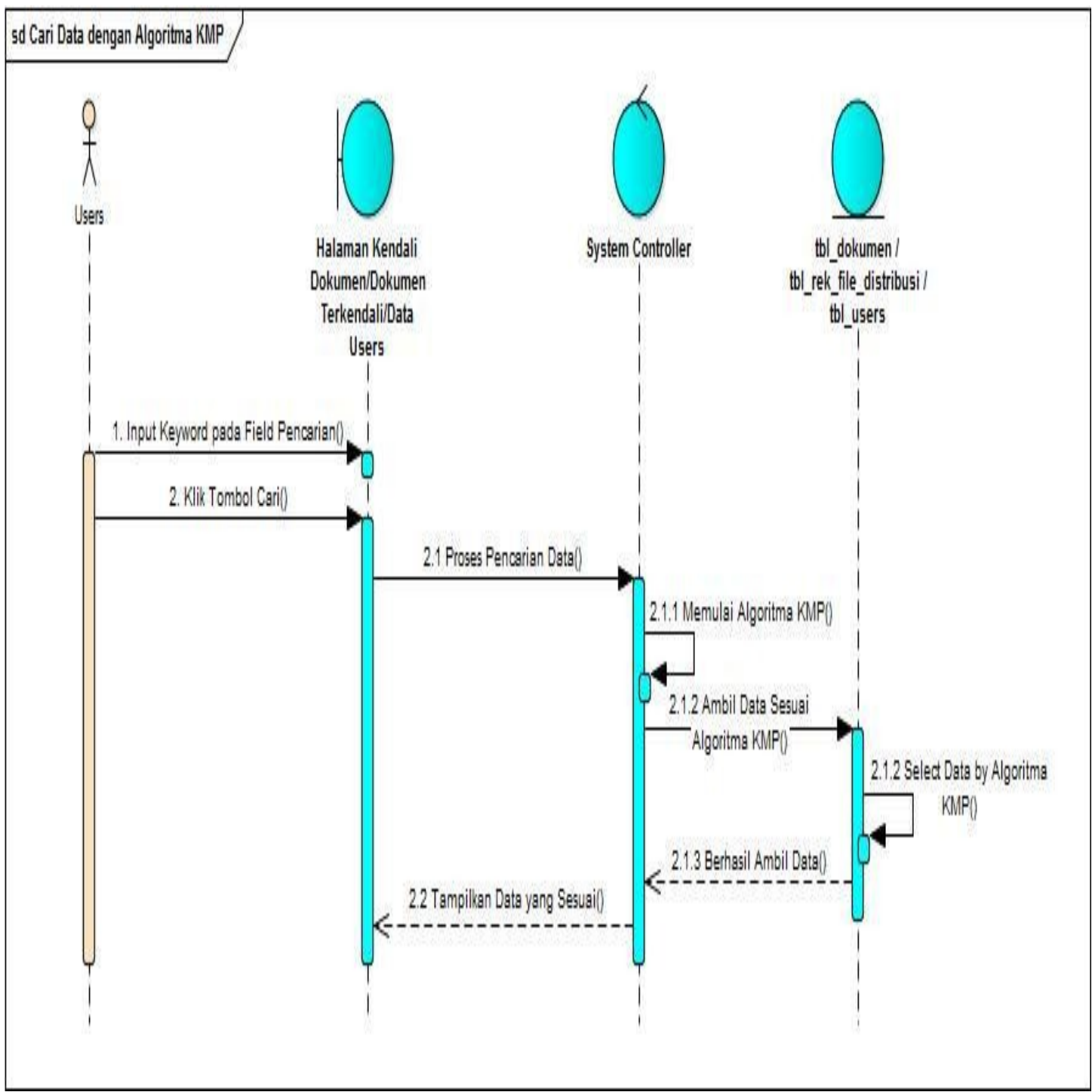

Gambar 7. Sequence Diagram Cari Data dengan Algoritma

\subsubsection{Class Diagram}

Class Diagram struktur rancangan sistem yang akan diterapkan dalam Sistem Informasi Administrasi Sekolah disajikan pada Gambar 8. 


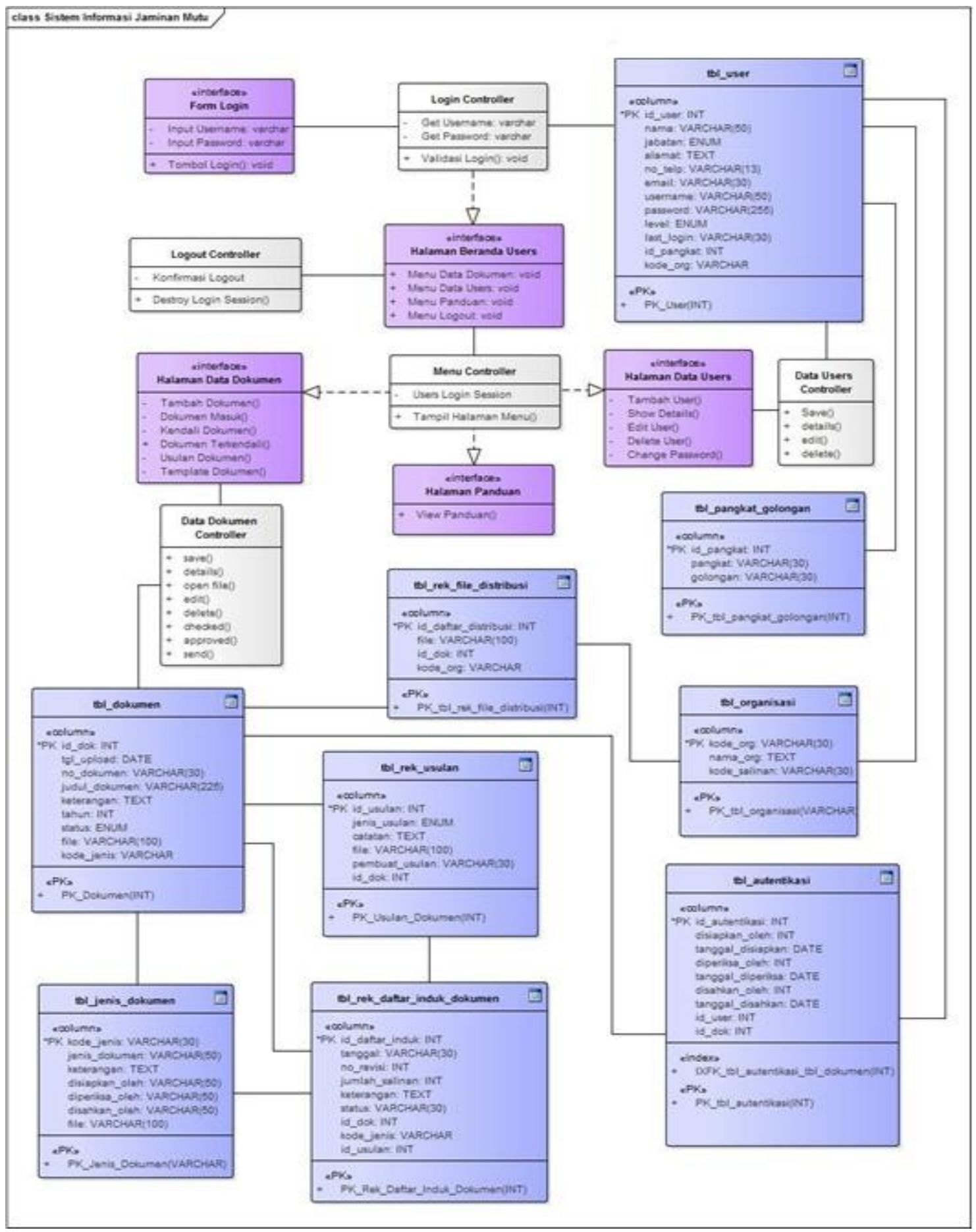

Gambar 8. Class Diagram

\subsection{Analisa Algoritma Knuth-Morris-Pratt}

Algoritma yang digunakan untuk pencocokan string pada fungsi pencarian Sistem Informasi Administrasi Sekolah yaitu menggunakan algoritma Knuth-Morris-Pratt (KMP). Algoritma KMP merupakan algoritma yang dikembangkan secara terpisah oleh D. E. Knuth pada tahun 1967, dan J.H. Morris bersama V.R. Pratt pada tahun 1966, namun keduanya mempublikasikan secara bersamaan 
Imam Maulana, Normalisa.

Penerapan Algoritma Knuth-Morris-Pratt pada Fungsi Pencarian Dokumen untuk Sistem Informasi Administrasi Sekolah Berbasis Website.

pada tahun 1977 [4].

Psudocode alogaritma KMP.

\begin{tabular}{|c|c|}
\hline Fase Pra-Pencarian & Fase Pencarian \\
\hline 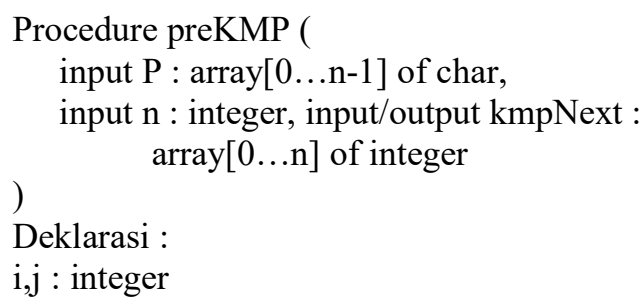 & $\begin{array}{l}\text { Procedure KMPSearch( input } \mathrm{m}, \mathrm{n} \text { : } \\
\text { integer, } \\
\text { input } \mathrm{P}: \text { array }[0 \ldots \mathrm{n}-1] \text { of char, } \\
\text { input } \mathrm{T}: \operatorname{array}[0 \ldots \mathrm{m}-1] \text { of char, } \\
\text { output ketemu }: \text { array }[0 \ldots \mathrm{m}- \\
1 \text { of boolean } \\
\text { ) }\end{array}$ \\
\hline 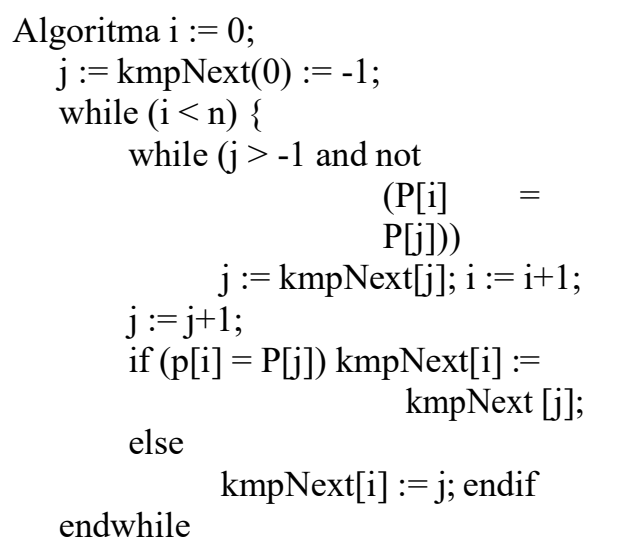 & 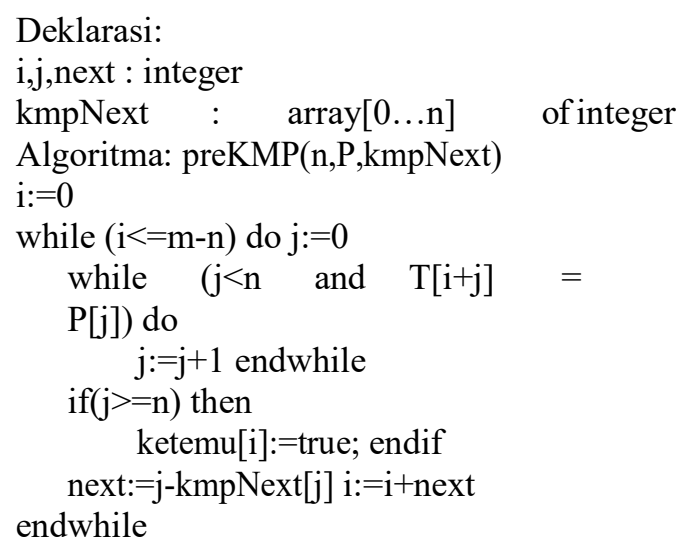 \\
\hline
\end{tabular}

Berdasarkan pseudocode tersebut, dapat diketahui langkah-langkah yang dilakukan algoritma Knuth-Morris-Pratt pada saat mencocokkan string adalah sebagai berikut:

Algoritma Knuth-Morris-Pratt mulai mencocokkan pattern pada awal teks.

1. Dari kiri ke kanan, algoritma ini akan mencocokkan karakter per karakter pattern dengan karakter di teks yang bersesuaian, sampai salah satu kondisi berikut dipenuhi adalah Karakter di pattern dan di teks yang dibandingkan tidak cocok (mismatch) serta Semua karakter di pattern cocok. Kemudian algoritma akan memberitahukan penemuan di posisi ini.

2. Algoritma kemudian menggeser pattern berdasarkan tabel next, lalu mengulangi langkah $b$ sampai pattern berada di ujung teks. Penerapan algoritma Knuth-Morris-Pratt pada fungsi pencarian dokumen untuk Sistem Informasi Administrasi Sekolah dijelaskan dalam beberapa langkah berikut:

String S:

\begin{tabular}{|l|l|l|l|l|l|l|l|l|}
\hline S & o & p & t & e & k & n & i & s \\
\hline
\end{tabular}

Pattern P:

$\begin{array}{llllllllll}\mathrm{T} & \mathrm{e} & \mathrm{k} & \mathrm{n} & \mathrm{i} & \mathrm{s}\end{array}$ 
Imam Maulana, Normalisa.

Penerapan Algoritma Knuth-Morris-Pratt pada Fungsi Pencarian Dokumen untuk Sistem Informasi Administrasi Sekolah Berbasis Website.

Langkah 1, bandingkan $\mathrm{P}(1)$ dengan $\mathrm{S}(1)$

\begin{tabular}{|l|l|l|l|l|l|l|l|l|}
\hline S & o & p & t & e & k & n & i & s \\
\hline
\end{tabular}
\begin{tabular}{|l|l|l|l|l|l|}
\hline T & e & k & n & i & s \\
\hline
\end{tabular}

$\mathrm{P}(1)$ tidak cocok dengan $\mathrm{S}(1)$, maka pattern akan bergeser satu posisi ke kanan. Langkah 2, bandingkan $\mathrm{P}(1])$ dengan $\mathrm{S}(2)$

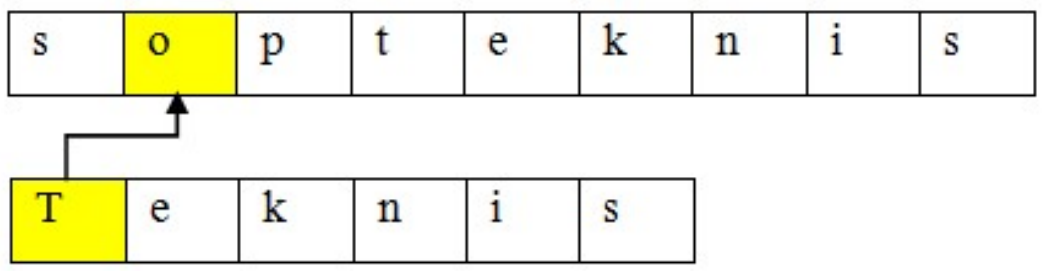

$\mathrm{P}(1)$ tidak cocok dengan $\mathrm{S}(2)$, maka pattern akan bergeser satu posisi ke kanan. Langkah 3, bandingkan $\mathrm{P}(1)$ dengan $\mathrm{S}(3)$

\begin{tabular}{|c|c|c|c|c|c|c|c|c|}
\hline $\mathbf{s}$ & o & $\mathrm{p}$ & $\mathrm{t}$ & $\mathrm{e}$ & $\mathrm{k}$ & $\mathrm{n}$ & $\mathrm{i}$ & $\mathrm{s}$ \\
\hline & & & & & & & & \\
\hline $\mathrm{T}$ & $\mathrm{e}$ & $\mathrm{k}$ & $\mathrm{n}$ & $\mathrm{i}$ & $\mathrm{s}$ & & & \\
\hline
\end{tabular}

$\mathrm{P}(1)$ tidak cocok dengan $\mathrm{S}(3)$, maka pattern akan bergeser satu posisi ke kanan. Langkah 4, bandingkan $\mathrm{P}(1)$ dengan $\mathrm{S}(4)$

\begin{tabular}{|l|l|l|l|l|l|l|l|l|}
\hline s & o & p & t & e & k & n & i & s \\
\hline
\end{tabular}
\begin{tabular}{|l|l|l|l|l|l|}
\hline T & e & k & n & i & s \\
\hline
\end{tabular}

$\mathrm{P}(1)$ cocok dengan S(4), maka algoritma Knuth-Morris-Pratt akan menyimpan informasi ini, dan pattern tidak akan melakukan pergeseran dan melanjutkan pencocokan $\mathrm{P}(2)$ dengan $\mathrm{S}(5)$. Langkah 5 , bandingkan $\mathrm{P}(2)$ dengan $\mathrm{S}(5)$

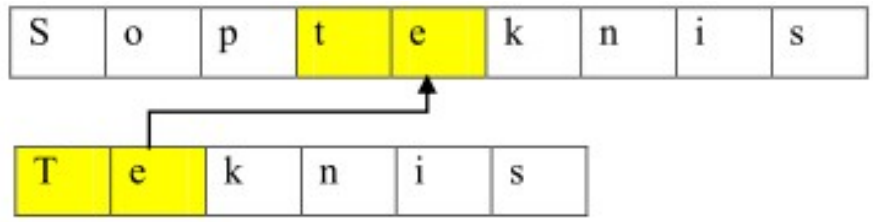


$P(2)$ cocok dengan $S(5)$, maka algoritma Knuth-Morris-Pratt akan menyimpan informasi ini, dan pattern tidak akan melakukan pergeseran dan melanjutkan pencocokan $P(3)$ dengan $S(6)$.

Langkah 6, bandingkan $P(3)$ dengan $S(6)$

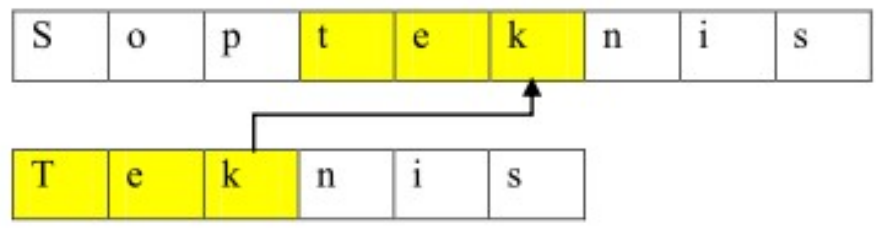

$P(3)$ cocok dengan $S(6)$ maka algoritma Knuth-Morris-Pratt akan menyimpan informasi ini, dan pattern tidak akan melakukan pergeseran dan melanjutkan pencocokan $P(4)$ dengan $S(7)$. Langkah 7 , bandingkan $P(4)$ dengan $S(7)$

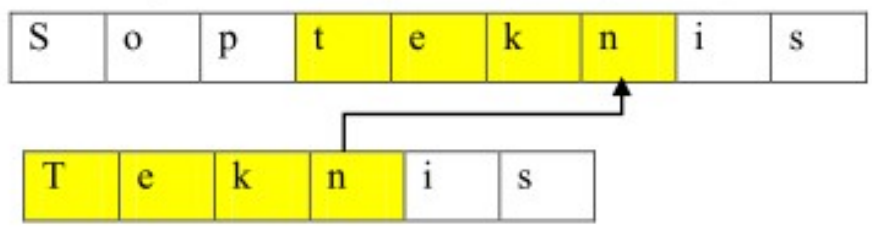

$P(4)$ cocok dengan $S(7)$ maka algoritma Knuth-Morris-Pratt akan menyimpan informasi ini, dan pattern tidak akan melakukan pergeseran dan melanjutkan pencocokan $P(5)$ dengan $S(8)$ Langkah 8 , bandingkan $P(5)$ dengan $S(8)$.

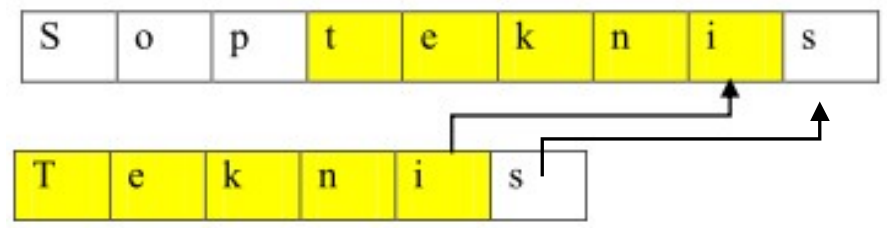

$P(5)$ cocok dengan $S(8)$ maka algoritma Knuth-Morris-Pratt akan menyimpan informasi ini, dan pattern tidak akan melakukan pergeseran dan melanjutkan pencocokan $P(9)$ dengan $S(8)$. Langkah 9, bandingkan $P(6)$ dengan $S(9)$

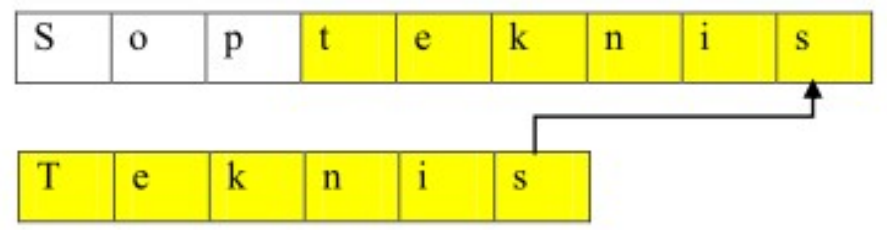

$P(6)$ cocok dengan $S(9)$, maka algoritma Knuth-Morris-Pratt akan menyimpan informasi ini, dan pattern tidak akan melakukan pergeseran dan melanjutkan pencocokan $P(7)$ dengan $S(10)$. Namun karena jumlah pattern hanya 6 huruf, maka pencarian akan dihentikan dan diperoleh hasil bahwa pattern $\mathrm{P}$ terdapat kecocokan dengan string $\mathrm{S}$ sebesar 100 persen. Jika semua huruf pada pattern sudah dicocokan dengan string, maka akan ditemukan sebuah pola kosakata di dalam string. Dalam menemukan sebuah pola pattern di dalam string akan dilakukan pergeseran beberapa kali untuk mencocokan setiap huruf pada pattern yang dimulai dari sebelah kiri untuk mencocokan setiap huruf pada string. Flowchart Algoritma Knuth-Morris-Pratt disajikan pada Gambar 24. 


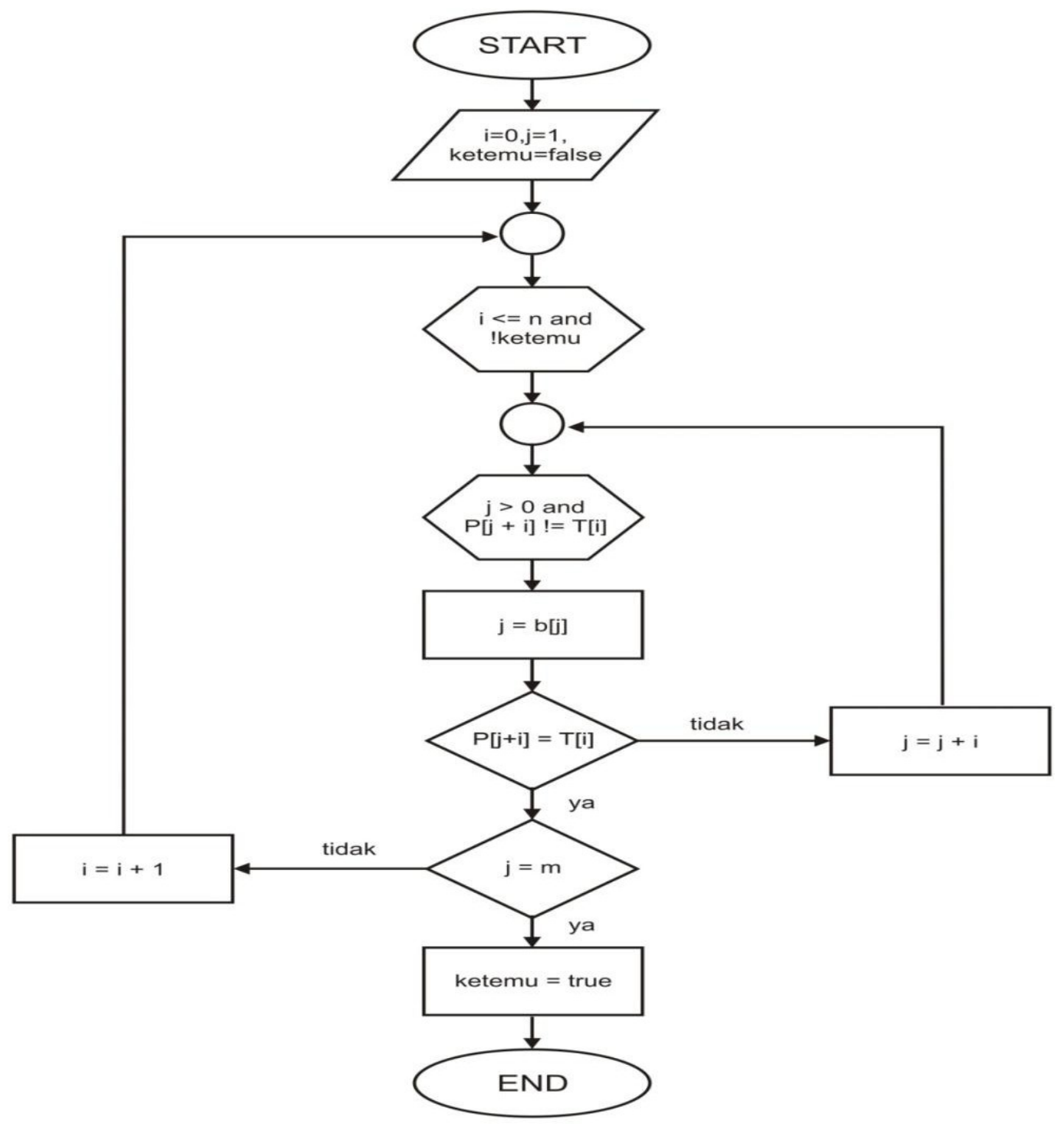

Gambar 9. Flowchart Algoritma Knuth-Morris-Pratt

\section{Implementasi dan Pengujian}

\subsection{Implementasi Perangkat Keras}

Website yang telah dirancang maka dibutuhkan perangkat keras sebagai tempat untuk menerapkannya. Adapun Perangkat keras yang dibutuhkan disajikan pada Tabel 2.

Tabel 2. Perangkat Keras

\begin{tabular}{c|c|c}
\hline No. & Nama & Spesifikasi Minimum \\
\hline 1. & Processor & AMD C-70 1.00 GHz (Atau setara) \\
\hline 2. & RAM & $2 \mathrm{~GB}$ \\
\hline 3. & Monitor & 11.3 " Radeon $^{\mathrm{TM}}$ HD Graphics \\
\hline
\end{tabular}


Imam Maulana, Normalisa.

Penerapan Algoritma Knuth-Morris-Pratt pada Fungsi Pencarian Dokumen untuk Sistem Informasi Administrasi Sekolah Berbasis Website. International Journal of Artificial Intelligence, vol. 6, no. 1, pp. 1-20, June 2019. DOI: 10.36079/lamintang.ijai-0601.30

\subsection{Implementasi Perangkat Lunak}

Perangkat lunak yang digunakan untuk mengimplementasikan sistem disajikan pada Tabel 3.

Tabel 3. Perangkat Lunak

\begin{tabular}{cll}
\hline No. & \multicolumn{1}{c}{ Tools } & \multicolumn{1}{c}{ Software Pendukung } \\
\hline 1. & Web Browser & Mozilla Firefox 52.0.1 (32 bit) \\
\hline 2. & XAMPP & XAMPP for Windows 5.6.14 \\
\hline 3. & PHP & PHP Version 5.6.14 \\
\hline 4. & Database & MariaDB (MySQLi Extentions) \\
\hline
\end{tabular}

\subsection{Implementasi Antarmuka}

Implementasi antarmuka halaman beranda disajikan pada Gambar 10.

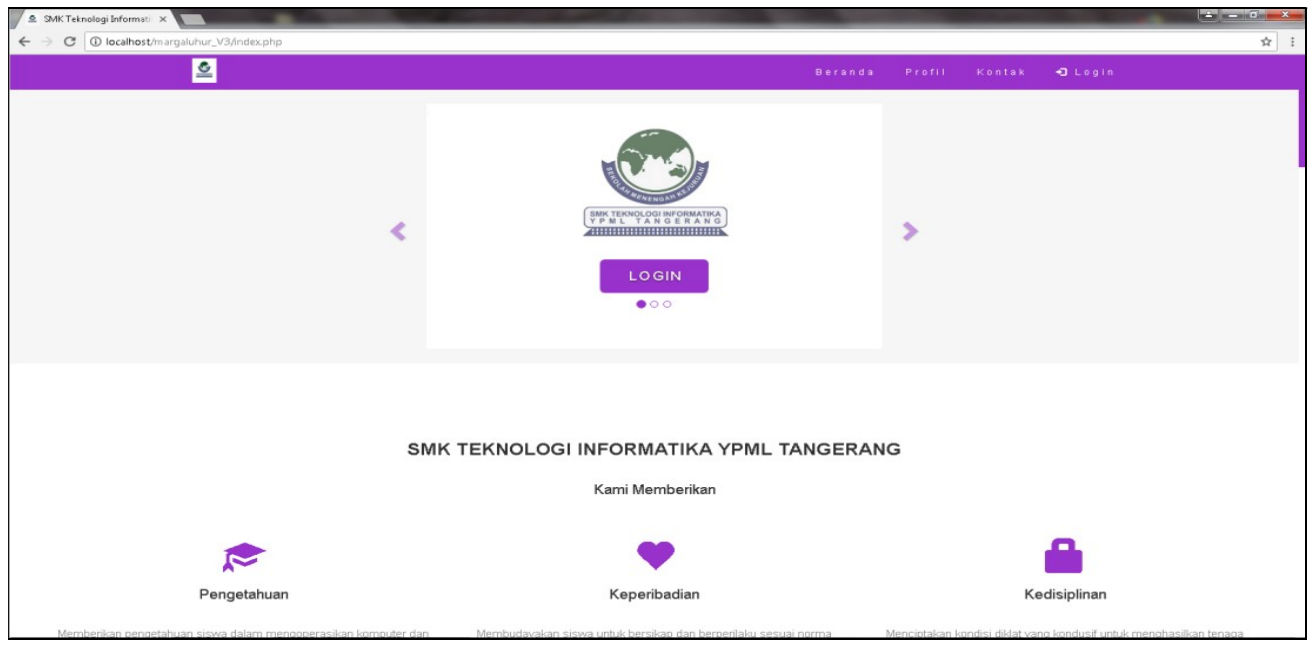

Gambar 10. Implementasi Halaman Beranda

Struktur menu yang terdapat pada halaman beranda yang dapat diakses oleh pengguna Sistem Informasi Administrasi Sekolah dapat dilihat pada Tabel 4.

Tabel 4. Struktur Menu Halaman Beranda

\begin{tabular}{cl}
\hline Menu & \multicolumn{1}{c}{ Deskripsi } \\
\hline Beranda & $\begin{array}{l}\text { Menu ini menampilkan halaman beranda Sistem } \\
\text { Informasi Administrasi Sekolah. }\end{array}$ \\
\hline Profil & Menu ini menampikan profil dari instansi terkait. \\
\hline Kontak & $\begin{array}{l}\text { Menu ini menampilkan kontak staf yang berwenang } \\
\text { pada SMK TI YPML Tangerang. }\end{array}$ \\
\hline Login & $\begin{array}{l}\text { Menu ini menampilkan form Login users untuk } \\
\text { masuk ke sistem. }\end{array}$ \\
\hline
\end{tabular}

Implementasi antarmuka form login dapat dilihat pada Gambar 11. 


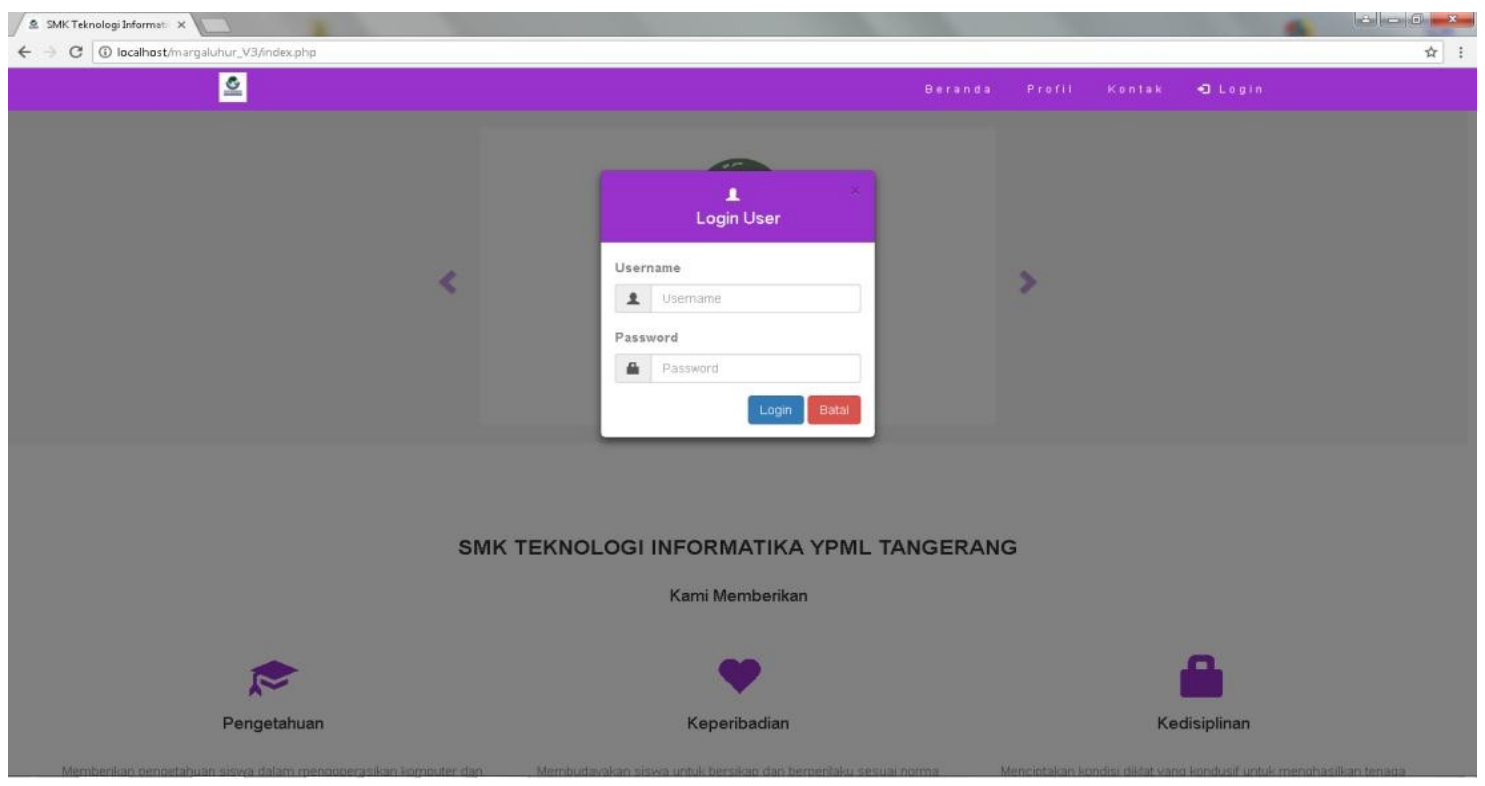

Gambar 11. Implementasi Form Login

Struktur komponen yang terdapat pada form Login yang dapat diakses oleh pengguna Sistem Informasi Administrasi Sekolah disajikan pada Tabel 5.

Tabel 5. Struktur Komponen Form Login

\begin{tabular}{ll}
\hline \multicolumn{1}{c}{ Komponen } & \multicolumn{1}{c}{ Deskripsi } \\
\hline Login Header & $\begin{array}{l}\text { Komponen ini menampilkan judul form dan tombol close untuk menutup form } \\
\text { Login. }\end{array}$ \\
\hline Field Username & Komponen ini digunakan untuk menampung input dari users berupa username. \\
\hline Field Password & Komponen ini digunakan untuk menampung input dari users berupa password. \\
\hline Tombol Login & $\begin{array}{l}\text { Komponen ini digunakan untuk memproses input dari users berupa validasi } \\
\text { Login. }\end{array}$ \\
\hline Tombol Batal & Komponen ini digunakan untuk menutup form Login. \\
\hline
\end{tabular}

\subsection{Pengujian Blackbox dan Whitebox}

\subsubsection{Blackbox}

Pengujian Blackbox merupakan pengujian software berfokus pada persyaratan fungsionalnya. Rencana pengujian blackbox disajikan pada Tabel 6. 
Tabel 6. Rencana Pengujian

\begin{tabular}{lc}
\hline \multicolumn{1}{c}{ ITEM UJI } & JENIS PENGUJIAN \\
\hline Login & Blackbox \\
\hline Tambah Dokumen & Blackbox \\
\hline Kendali Dokumen & Blackbox \\
\hline Buat Usulan Dokumen & Blackbox \\
\hline Kelola Template Dokumen & Blackbox \\
\hline Kelola Data Users & Blackbox \\
\hline Pencarian Data dengan Algoritma KMP & Blackbox \\
\hline
\end{tabular}

Contoh Pengujian ujian login disajikan pada Tabel 7.

Tabel 7. Pengujian Login

\begin{tabular}{|c|c|c|c|}
\hline \multicolumn{4}{|c|}{ KASUS DAN HASIL UJI (DATA BENAR) } \\
\hline $\begin{array}{l}\text { DATA YANG } \\
\text { DIMASUKAN }\end{array}$ & $\begin{array}{c}\text { YANG } \\
\text { DIHARAPKAN } \\
\end{array}$ & PENGAMATAN & KESIMPULAN \\
\hline $\begin{array}{l}\text { Input username dan } \\
\text { password sesuai data } \\
\text { user. }\end{array}$ & $\begin{array}{l}\text { Dapat login dan masuk } \\
\text { ke halaman beranda } \\
\text { user. }\end{array}$ & $\begin{array}{l}\text { Menampilkan pesan } \\
\text { Berhasil Logindan halaman } \\
\text { beranda user, seperti yang } \\
\text { diharapkan. }\end{array}$ & $\begin{array}{l}\text { (ل) Sesuai } \\
\text { () Tidak Sesuai }\end{array}$ \\
\hline \multicolumn{4}{|c|}{ KASUS DAN HASIL UJI (DATA SALAH) } \\
\hline $\begin{array}{l}\text { Input username dan } \\
\text { password tidak } \\
\text { sesuai data } \text { user. }\end{array}$ & $\begin{array}{l}\text { Tidak dapat login dan } \\
\text { Masuk ke halaman } \\
\text { beranda } \text { user. }\end{array}$ & $\begin{array}{l}\text { Menampilkan pesan Gagal } \\
\text { Login dan kembali ke } \\
\text { halaman beranda website. }\end{array}$ & $\begin{array}{l}\text { ( } \sqrt{\text { ) Sesuai }} \\
\text { ( ) Tidak Sesuai }\end{array}$ \\
\hline $\begin{array}{l}\text { Username dan } \\
\text { password di- biarkan } \\
\text { kosong lalu tekan } \\
\text { tombol Login. }\end{array}$ & $\begin{array}{l}\text { Tidak dapat memproses } \\
\text { Login. }\end{array}$ & $\begin{array}{l}\text { Menampilkan pesan } \\
\text { username dan password } \\
\text { harus diisi pada field } \\
\text { username dan password. }\end{array}$ & $\begin{array}{l}\text { ( } \sqrt{\text { ) Sesuai }} \\
\text { ( ) Tidak Sesuai }\end{array}$ \\
\hline
\end{tabular}

Pengujian Pencarian Data dengan Algoritma KMP disajikan pada Tabel 8.

Tabel 8. Pengujian Pencarian Data dengan Algoritma KMP

\begin{tabular}{|c|c|c|c|}
\hline \multicolumn{4}{|c|}{ KASUS DAN HASIL UJI (DATA BENAR) } \\
\hline $\begin{array}{l}\text { DATA YANG } \\
\text { DIMASUKAN }\end{array}$ & $\begin{array}{c}\text { YANG } \\
\text { DIHARAPKAN }\end{array}$ & PENGAMATAN & KESIMPULAN \\
\hline $\begin{array}{l}\text { Input keyword pada } \\
\text { field pencarian lalu } \\
\text { klik tombol Cari. }\end{array}$ & $\begin{array}{l}\text { Dapat memproses } \\
\text { pencarian data dengan } \\
\text { algoritma } \\
\text { KMP. }\end{array}$ & $\begin{array}{l}\text { Menampilkan data yang } \\
\text { ditemukan } \\
\text { pada tabel. }\end{array}$ & $\begin{array}{l}\text { (v) Sesuai } \\
\text { ( ) Tidak Sesuai }\end{array}$ \\
\hline \multicolumn{4}{|c|}{ KASUS DAN HASIL UJI (DATA SALAH) } \\
\hline $\begin{array}{l}\text { Form Input } \\
\text { pencarian data } \\
\text { dibiarkan kosong } \\
\text { lalu tekan tombol } \\
\text { Cari. }\end{array}$ & $\begin{array}{l}\text { Tidak dapat memproses } \\
\text { pencarian dengan } \\
\text { algoritma KMP. }\end{array}$ & $\begin{array}{l}\text { Menampilkan pesan form } \\
\text { input harus diisi. }\end{array}$ & $\begin{array}{l}\text { (ل) Sesuai } \\
\text { ( ) Tidak Sesuai }\end{array}$ \\
\hline
\end{tabular}


Imam Maulana, Normalisa.

Penerapan Algoritma Knuth-Morris-Pratt pada Fungsi Pencarian Dokumen untuk Sistem Informasi Administrasi Sekolah Berbasis Website.

International Journal of Artificial Intelligence, vol. 6, no. 1, pp. 1-20, June 2019. DOI: 10.36079/lamintang.ijai-0601.30

\subsubsection{Whitebox}

Uji Whitebox Sistem Informasi Administrasi Sekolah pada bagian validasi data, login user dan pencarian dokumen dengan KMP, disajikan pada Tabel 9.

Tabel 9. Pengujian Whitebox Sistem Informasi Administrasi Sekolah

\begin{tabular}{|c|c|c|}
\hline PENGUJIAN & $\begin{array}{c}\text { TEST CASE } \\
\text { BENAR }\end{array}$ & $\begin{array}{c}\text { TEST CASE } \\
\text { SALAH }\end{array}$ \\
\hline $\begin{array}{l}\text { if (isset(\$_POST['username'])) }\{ \\
\text { \$username = \$_POST['username']; } \\
\text { \$password = } \\
\text { md5(\$_POST['password']); }\end{array}$ & $\begin{array}{l}\text { Untuk validasi } \\
\text { data }\end{array}$ & $\begin{array}{l}\text { Tidak dapat } \\
\text { melakukan }\end{array}$ \\
\hline 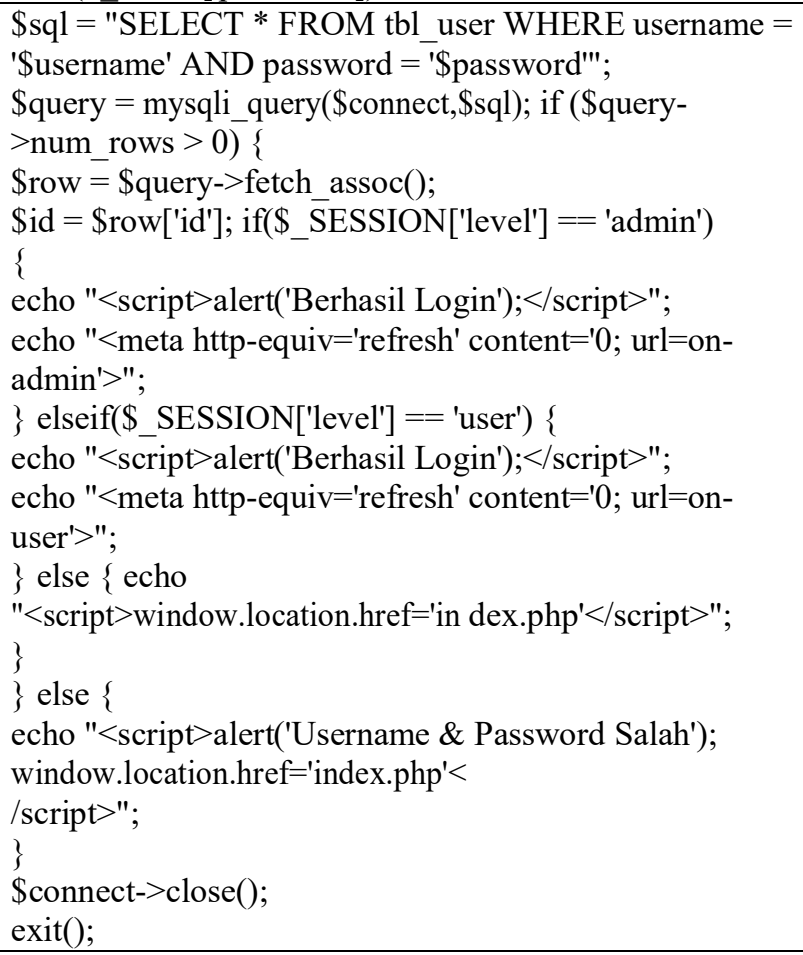 & login user. & $\begin{array}{c}\text { validasi data login } \\
\text { user. }\end{array}$ \\
\hline $\begin{array}{l}\text { \$keyword = \$_GET['keyword']; } \\
\text { \$search = explode(' ', \$keyword); } \\
\text { \$sql = "SELECT * FROM tbl_dokumen WHERE } \\
\text { status='Telah Didistribusi' AND ( "; } \\
\text { \$parts = array(); } \\
\text { \$kata = array(); foreach(\$search as \$search_word) } \\
\text { \{ } \\
\text { \$parts[] = 'tgl_upload LIKE "\%'.\$search_word.'\%"'; } \\
\text { \$parts[] = 'kode_jenis LIKE "\%'.\$search_word.'\%"'; } \\
\text { \$parts[] = 'no_dokumen LIKE "\%'.\$search_word.'\%"'; } \\
\text { \$parts[] = 'judul_dokumen LIKE "\%'.\$search_word.'\%"'; } \\
\text { \$parts[] = 'keterangan_output LIKE } \\
\text { "\%'.\$search_word.'\%"'; } \\
\text { \$parts[] = 'tahun_prioritas LIKE "\%'.\$search_word.'\%"'; } \\
\text { \$kata[] = \$search_word; } \\
\text { \} } \\
\text { \$dapat = implode(' ', \$kata); } \\
\text { \$sql .= implode(' OR ', }\end{array}$ & $\begin{array}{c}\text { Sistem akan } \\
\text { mencari data } \\
\text { dengan algoritma } \\
\text { KMP. }\end{array}$ & Tidak ada reaksi. \\
\hline
\end{tabular}




\section{Kesimpulan}

Berdasarkan hasil perancangan, implementasi dan pengujian Sistem Informasi Administrasi Sekolah dengan menerapkan algoritma Knuth-Morris-Pratt untuk fungsi pencarian dokumen dan data lain yang berkaitan dengan sistem, maka dapat diambil kesimpulan bahwa perancangan dan pembangunan Sistem Informasi Administrasi Sekolah terbukti dapat membantu SMK TI YPML Tangerang dalam mengendalikan dokumen sehingga lebih efektif dan efisien. Penyimpanan data dokumen pada database terbukti dapat menyediakan backup data secara digital sehingga aman ketika terjadi kerusakan atau kehilangan terhadap dokumen fisik. Penerapan algoritma Knuth-Morris-Pratt pada fungsi pencarian dokumen di database terbukti menampilkan hasil yang lebih tepat.

\section{Daftar Pustaka}

[1] M. Rossaria, B. Susilo, and Ernawati, "Implementasi Algoritma Pencocokan String KnuthMorris-Pratt dalam Aplikasi Pencarian Dokumen Digital Berbasis Android", Jurnal Rekursif, vol. 3, no. 2, pp. 183-195, 2015.

[2] H. T. Sa'diah, "Implementasi Algoritma Knuth-Morris-Pratt pada Fungsi Pencarian Judul Tugas Akhir Repository", Jurnal Komputasi, vol. 14, no. 1, pp. 1-9, 2017.

[3] R. J. McLeod, System Development: A Project Management Approach, New York: Leigh Publishing LLC, 2002.

[4] Munawar, Pemodelan Visual dengan UML, Yogyakarta: Graha Ilmu, 2005.

[5] Ramdhani, A. Sukmaji, and T. Sutanto, "Rancang Bangun Aplikasi Pencarian Ayat AlS.Qur'an Menggunakan Metode Algoritma String Matching Knuth-Morris-Pratt Berbasis Android," JSIKA, vol. 4, no. 1, pp. 1-7, 2015.

[6] M. S. Badri, Manajemen Administrasi Perkantoran Modern. Jakarta: Penerbit Erlangga, 2007.

[7] Jogiyanto, Analisis dan Desain Sistem Informasi, Jakarta: Andi, 2005

[8] M. C. Utami, and Y. T. Hutomo, "Penerapan Waterfall dalam Analisis dan Perancangan Sistem Informasi Manajemen Dokumen Surat Menyurat pada Bank BJB Kantor Cabang BSD Tangerang", Jurnal Sains,Teknologi dan Industri, vol. 12, no. 1, pp. 129-135, 2014.

[9] D. A. Prapto, and M. Purwaningsih, "Pengembangan Aplikasi Dokumen Manajemen untuk Departemen Pemerintahan," Seminar Nasional Informatika 2008 (semnasIF 2008), pp. 82-87, 2008.

[10] Tukino, "Perancangan Sistem Informasi Manajemen Proyek Pengaksessan Dokumen Perakitan PCBA," di PT Surya Teknologi Batam Berbasis Web, TEKNOSI (Jurnal Teknologi dan Sistem Informasi), vol. 2, no. 3, pp. 67-84, 2016. 